\title{
The Isolation and
}

\section{Characterization of Alkane-oxidizing Organisms and the Effect of Growth Substrate on Isocitric Lyase}

\author{
By T. J. TRUST* AND NANCY F. MILLIS \\ School of Microbiology, University of Melbourne, Parkville, Victoria, Australia
}

(Accepted for publication 23 January 1970)

\section{SUMMARY}

A mycobacterium, two pseudomonads and a torula were isolated from soil using selective enrichment techniques in mineral salts-kerosene media. The properties of the organisms and their possible identity are outlined. Hydrocarbons, fatty acids, $n$-alcohols, dicarboxylic acids and acyl amides able to support growth were determined. Growth of the torula on hydrocarbons increased the ability of the organisms to oxidize other alkanes and fatty acids; the organism was, however, able to oxidize these substrates, at a slow rate, irrespective of the substrate of growth. When the torula was grown on an alkane with an even number of carbon atoms, there was no evidence that the induced enzymes favoured the oxidation of fatty acids with even rather than odd numbers of carbon atoms.

Growth on hydrocarbons increased the amount of isocitric lyase present in all four micro-organisms, suggesting that $\beta$-oxidation of fatty acids derived from alkanes gives rise to acetyl-CoA and that this pathway and the glyoxylate bypass are important in the metabolism of alkanes.

\section{INTRODUCTION}

The metabolism of straight-chain hydrocarbons by micro-organisms has been reviewed by Foster (1962), Johnson (1967), McKenna \& Kallio (1965), and van der Linden \& Thijsse (1965). It is generally agreed that the primary attack on $n$-alkanes is by oxidation of the terminal methyl group to a carboxyl group. There is evidence that diterminal oxidation also occurs (Kester \& Foster, 1963), but it is probable that this is a minor pathway. In both cases, the major pathway for the subsequent metabolism of the fatty acid is thought to be by $\beta$-oxidation to yield acetyl-coenzyme $\mathrm{A}$ units. Since the organisms would thus be growing essentially on acetate, it might be expected that isocitric lyase (EC 4.I.3.I), a key enzyme of the glyoxylate bypass, would be induced by prior growth on $n$-alkanes. This paper reports assays for this enzyme in cells grown on alkane and non-alkane substrates.

It is still commonly said that prior growth on alkanes induces oxidation systems in the cells such that the fatty acids in the homologous series, each with two carbon atoms less than the alkane used for growth, are oxidized more rapidly than the fatty acids with one, three, five, etc. less carbon atoms. Azoulay \& Senez (I960) claim such sequential induction in a pseudomonad grown on $\mathrm{C}_{10}, \mathrm{C}_{8}, \mathrm{C}_{7}$ or $\mathrm{C}_{6}$ alkanes. Although they obtained some data inconsistent with this interpretation, they attributed these results to impurities in their reagents. The results of Thijsse \& van der Linden (1958,

* Present address: Department of Bacteriology and Biochemistry, University of Victoria, Victoria, British Columbia, Canada. 
1963) with heptane or hexane-grown pseudomonads did not show sequential induction nor were Treccani, Canonica \& de Girolamo (1955) able to demonstrate this phenomenon with Nocardia, Achromobacter or Mycobacterium grown on $\mathrm{C}_{12}, \mathrm{C}_{8}, \mathrm{C}_{7}, \mathrm{C}_{6}$, $\mathrm{C}_{5}$ alkanes or $\mathrm{C}_{6}$ or $\mathrm{C}_{5}$ fatty acids.

This paper reports first the isolation and characterization of widely different organisms, pseudomonads, a mycobacterium and a torula, capable of growth on alkanes as the sole source of carbon. The organisms were then tested for their ability to grow on a number of alkanes and fatty acids. In addition, the effect of the growth substrate on the ability of the torula to oxidize likely metabolites was investigat ed. While the enzyme systems concerned in the oxidation of alkanes and fatty acids were induced by prior growth on alkanes, there was no evidence of sequential induction of the enzymes associated with the oxidation of the series of fatty acids with two less carbon atoms than the alkane used for growth.

\section{METHODS}

Media. The basal mineral salts medium contained (g./1.): $\mathrm{MgSO}_{4} \cdot 7 \mathrm{H}_{2} \mathrm{O}, 0.04$; $\mathrm{CaCl}_{2} .6 \mathrm{H}_{2} \mathrm{O}, 0.02 ; \mathrm{FeSO}_{4} .6 \mathrm{H}_{2} \mathrm{O}, 0.002 ; \mathrm{NH}_{4} \mathrm{Cl}, 2 \cdot 7 ; \mathrm{KH}_{2} \mathrm{PO}_{4}, 8 \cdot 5 ; \mathrm{Na}_{2} \mathrm{HPO}_{4}, 8.9$. The modified mineral salts medium used for the isolation of the torula was made in tap water and contained (g./l.): $\mathrm{MgSO}_{4} \cdot 7 \mathrm{H}_{2} \mathrm{O}, 0 \cdot 5 ; \mathrm{NH}_{4} \mathrm{Cl}_{2}, \mathrm{I} \cdot 0 ; \mathrm{KH}_{2} \mathrm{PO}_{4}, \mathrm{I} \cdot 0 ; \mathrm{Difco}$ yeast extract, 0.25 . This medium was adjusted to $\mathrm{pH} 5.5$ by the addition of $0.25 \mathrm{M}$ $\mathrm{NaOH}$. All media were autoclaved at $15 \mathrm{lb}$./sq. in. for $15 \mathrm{~min}$. D-Glucose solution $25 \%(\mathrm{w} / \mathrm{v})$ was autoclaved at $5 \mathrm{lb}$. $/ \mathrm{sq}$. in. for $25 \mathrm{~min}$. and added to sterile basal mineral salts medium to give $0.05 \mathrm{M}$ concentration. Sodium acetate was added to give $0.05 \mathrm{M}$ in the mineral salts medium before the medium was autoclaved. Carboxylic acids were added to the basal mineral salts medium to give $0.005 \mathrm{M}$ before the medium was autocalved. Seitz-filtered liquid alkane $(5 \mathrm{ml}$.) was added to $\mathrm{I} 1$. of the sterile mineral salts medium. Solid media were prepared by the addition of $\mathrm{I} \cdot 2 \%(\mathrm{w} / \mathrm{v})$ agar to liquid media. Pigment production was measured on King's media A and B (King, Ward \& Raney, 1954).

Isolation and maintenance of organisms. A hydrocarbon-utilizing torula was isolated from soil using selective enrichment with kerosene modified mineral salts $(\mathrm{pH} 5.5)$ medium. Hydrocarbon-utilizing pseudomonads were isolated from soil using kerosenebasal mineral salts medium at $\mathrm{pH} 7.0$ and a hydrocarbon-utilizing mycobacterium was isolated by selective enrichment on kerosene-mineral salts agar at $\mathrm{pH} 7 \cdot 0$.

Stock cultures were kept at $4^{\circ}$ on acetate-mineral salts agar slopes and were subcultured monthly. Freeze-dried cultures of all strains were kept as reserve stock.

Characterization of the organisms. The tests for the properties of the isolates were those described by Skerman (I967).

Tests for growth on hydrocarbons and fatty acids. The ability of the organisms to use various hydrocarbons and fatty acids as sole source of carbon and energy for growth was tested in $100 \mathrm{ml}$. of medium in shaken flasks. The cultures were incubated at $30^{\circ}$ and, after 7 days, the amount of growth in each flask was observed visually and recorded according to the following scale: $I+=$ light but definite turbidity; $2+=$ moderate turbidity; $3+=$ heavy turbidity.

Growth of cells for respiration and enzyme studies. Cells were grown at $30^{\circ}$ in 41 . batches in a 61 . glass fermenter. Air was passed into the fermenter at a rate of $41 . / \mathrm{min}$. and the agitator rotated from 600 to $1000 \mathrm{rev}$./min. After $36 \mathrm{hr}$, cultures were cooled 
and the cells centrifuged at $10,000 \mathrm{~g}$ for $\mathrm{I} 5 \mathrm{~min}$. at $4^{\circ}$. The cells were resuspended and washed in $0.02 \mathrm{M}-\mathrm{KH}_{2} \mathrm{PO}_{4}-\mathrm{Na}_{2} \mathrm{HPO}_{4}$ buffer $(\mathrm{pH} 7)$. Cells grown on glucose or acetate were washed twice; for those grown on hydrocarbons, six washes were necessary to remove the alkane.

Respiration studies. Cells were resuspended in $0.05 \mathrm{M}-\mathrm{KH}_{2} \mathrm{PO}_{4}-\mathrm{Na}_{2} \mathrm{HPO}_{4}$ buffer $(\mathrm{pH} 7)$ and the turbidity of the cell suspension was standardized to contain I mg. dry weight $/ \mathrm{ml}$. of buffer. The Warburg flasks contained $0.2 \mathrm{ml}$. of $20 \%(\mathrm{w} / \mathrm{v}) \mathrm{NaOH}$ in the centre well, $\mathrm{I}$ ml. of organisms and I ml. of $0.05 \mathrm{M}-\mathrm{KH}_{2} \mathrm{PO}_{4}-\mathrm{Na}_{2} \mathrm{HPO}_{4}$ buffer $(\mathrm{pH} 7)$ in the main compartment and either $0.2 \mathrm{ml}$. of liquid hydrocarbon, $50 \mathrm{mg}$. of solid hydrocarbon or $10 \mu$ moles of carboxylic acid $\left(\mathrm{pH}_{7}\right)$ in the side arm. To measure endogenous respiration, $0.2 \mathrm{ml}$. of distilled water replaced the substrate in the side arm. Measurements were made at $30^{\circ}$ in air. The $Q_{\mathrm{o}_{2}}(\mu$ l. of oxygen taken up $/ \mathrm{mg}$. dry weight of cells/hr) was calculated.

Preparation of crude cell-free extracts. After washing, I g. of wet cell paste was resuspended in $4 \mathrm{ml}$. of $0.05 \mathrm{M}-\mathrm{KH}_{2} \mathrm{PO}_{4}-\mathrm{Na}_{2} \mathrm{HPO}_{4}$ buffer $(\mathrm{pH} 7$ ) containing I mM-2mercaptoethanol and $\mathrm{I} \mathrm{mM}-\mathrm{MgCl}_{2}$. Cells were exposed to ultrasonic disintegration for five periods of $60 \mathrm{sec}$., care being taken not to overheat the cell suspension. Cell debris was removed by centrifugation at $13,000 \mathrm{~g}$ for $15 \mathrm{~min}$. at $4^{\circ}$; the supernatant was assayed for isocitric lyase activity.

Protein estimation. Protein was estimated by the biuret method of Gornall, Bardawill \& David (1949).

Assay of isocitric lyase. The method of Dixon \& Kornberg (1959) was used. The assay mixture contained roo $\mu$ moles $\mathrm{KH}_{2} \mathrm{PO}_{4}-\mathrm{Na}_{2} \mathrm{HPO}_{4}$ buffer $(\mathrm{pH} 7), 15 \mu$ moles $\mathrm{MgCl}_{2}$, Io $\mu$ moles phenylhydrazine $\mathrm{HCl}$, Io $\mu$ moles reduced glutathione, $5 \mu$ moles sodium (D,L)-isocitrate and cell-free extract in a final volume of $3 \mathrm{ml}$. The blank lacked substrate. Glyoxylate phenylhydrazone was estimated by measuring the increase in $\mathrm{OD}_{324}$ on incubation at $30^{\circ}$ and comparing this with a standard curve of glyoxylate phenylhydrazone. One unit of isocitric-lyase activity is defined as $m \mu$ moles phenylhydrazone formed $/ 5 \mathrm{~min}$. and the specific activity is expressed as units $/ \mathrm{mg}$. protein.

Chemicals. Hexadecane was American Standard Testing Material. The other alkanes used for growth and oxidation studies were supplied by Newton Maine Rare Chemicals guaranteed not less than $99 \%$ pure. The fatty acids were Sigma Grade supplied by Sigma Chemical Co. Mixed hydrocarbons were commercially available products of Mobil Oil Co., Australia. All other chemicals were of the highest purity commercially available and were not purified further.

\section{RESULTS}

Characteristics of Torulopsis $\mathrm{Y} 8$. The alkane-oxidizing torula, Torulopsis $\mathrm{Y} 8$ was a Gram-positive, non-capsulate oval organism (dimensions $2 \cdot 5-4 \mu \mathrm{m}$.) which stained regularly and divided by budding. After 2 days aerobic growth at $30^{\circ}$ on glucose-yeast extract agar, the matt colonies were circular, $1.5 \mathrm{~mm}$. diameter with a regular edge and a low convex elevation. They had a white opaque colour, fruity odour and a butyrous consistency. Despite repeated attempts to induce sporulation, spores were never observed.

Peptone, yeast extract, ammonium ions but not nitrate were able to act as sole nitrogen source for growth. Glucose, sucrose, and galactose, but not lactose, maltose or arabinose acted as the sole source of carbon for growth. The organism was unable 
to grow in ethanol-mineral salts medium. It produced acid from glucose and galactose after I day, a little acid from sucrose and raffinose after 2 days and a little acid from trehalose after 30 days. Fructose, maltose, xylose, arabinose, inositol, mannitol, glycerol and rhamnose were not fermented. The organism was able to metabolize glucose oxidatively and fermentatively. Litmus milk was made alkaline after 30 days.

Lodder \& Kreger-van Rij's The Yeasts, a Taxonomic Study (1952) was used for the identification of the organism. Torulopsis $Y 8$ appears to be similar to but not identical with Torulopsis gropengiensseri and Torulopsis magnoliae.

Characteristics of Pseudomonas 22 and Pseudomonas 14. The alkane-oxidizing pseudomonads 22 and 14 were Gram-negative, non-capsulated, evenly stained, nonsporing rods (dimensions $0.4 \times 0.8 \mu \mathrm{m}$.). Both were motile by means of a single polar flagellum. They metabolized glucose oxidatively but no acid was produced fermentatively after 17 days incubation. After 2 days aerobic growth at $30^{\circ}$ on nutrient agar, the smooth, creamy opalescent colonies were circular, $2 \mathrm{~mm}$. diameter with a regular edge and a low convex elevation; they had a foul ammoniacal odour and a butyrous consistency. Aerobic growth in nutrient broth at $30^{\circ}$ gave a dense uniform turbidity with a deposit and a slight ring pellicle; neither organism produced any pigment. Both organisms were able to grow at $I 2,22,30$ and $37^{\circ}$ but not at $45^{\circ}$ with an optimum at $30^{\circ}$. Neither organism produced a pigment in King's A, but organism 22 produced a yellowish green, water-soluble pigment in King's B which was not pyocyanin. On Dorset egg medium, strain 22 gave orange yellow pigmented growth, and strain 14 gave light yellow growth. Both organisms hydrolysed urea and tributyrin, but not gelatin, gave negative indole, methyl-red and Voges-Proskauer tests, and strain I 4 was able to reduce nitrate (no gas production). Neither was able to ferment maltose, inositol, sucrose, glycerol, mannitol, rhamnose, lactose, xylose, raffinose or trehalose. A small amount of acid was produced by both organisms from glucose after 3 days and by organism 14 from fructose and arabinose after 7 days.

In litmus milk, organism 22 produced an alkaline reaction after 3 days and weak reduction after I I days. Organism 14 produced acid and clot formation with slight reduction at 7 days and partial liquefaction of the clot at 18 days.

Using Bergey's Manual of Determinative Bacteriology (Breed, Murray \& Smith, 1957), Pseudomonas 22 was found to be similar to the Pseudomonas putida, P. striata and $P$. ovalis group; Pseudomonas $I 4$ was similar to the $P$. desmolytica, $P$. rattours and $P$. salopnia group.

The cells of Mycobacterium B 4 were irregularly Gram-positive, acid-fast, non-motile, non-capsulated, non-sporing rods $(0.8 \times 2.5 \mu \mathrm{m}$.). Some cells were pleomorphic with bent axes. After aerobic growth on nutrient agar for 2 days, the colonies were circular, I to $3 \mathrm{~mm}$. in diameter, with an irregular edge, flat, with a very wrinkled matt surface. The colonies had an orange-yellow pigment and were difficult to emulsify. No pigment was produced by growth on King A or King B medium, but yellow growth was produced on a potato slice after 2 days. The organism grew at 22, 30, 37 and $45^{\circ}$ but not at 12 or $52^{\circ} ; 37^{\circ}$ was the optimum temperature.

The organism hydrolysed urea and tributyrin but not gelatin. Cooked meat was not digested but a ring pellicle of growth did occur. The organism was indole-negative, methyl-red negative, Voges-Proskauer negative and nitrate negative, and produced weak acid from Hugh and Liefson medium aerobically after I4 days. Glycerol, inositol, 
Table I. Growth of Torulopsis Y 8, Pseudomonas 22, Pseudomonas 14 and Mycobacterium B4 on n-alkanes, mixed hydrocarbons, alcohols, monocarboxylic acids, dicarboxylic acids and acyl amides

\begin{tabular}{|c|c|c|c|c|c|}
\hline \multirow[b]{2}{*}{ Substrate } & \multirow{2}{*}{$\begin{array}{l}\text { Number } \\
\text { of carbon } \\
\text { atoms }\end{array}$} & \multicolumn{4}{|c|}{ Growth* after 6 days } \\
\hline & & Y 8 & 22 & 14 & B4 \\
\hline \multicolumn{6}{|l|}{ n-Alkanes } \\
\hline Hexane & 6 & 0 & $2+$ & 0 & 0 \\
\hline Octane & 8 & 0 & $2+$ & $\mathbf{I}+$ & 0 \\
\hline Decane & 10 & 0 & $2+$ & $I+$ & $I+$ \\
\hline Dodecane & 12 & $I+$ & $2+$ & $2+$ & $I+$ \\
\hline Tetradecane & I4 & $2+$ & $2+$ & $2+$ & $2+$ \\
\hline Hexadecane & 16 & $2+$ & $2+$ & $2+$ & $2+$ \\
\hline Octadecane & 18 & $\mathbf{I}+$ & $1+$ & $2+$ & $\mathrm{I}+$ \\
\hline Eicosane & 20 & $I+$ & $1+$ & $2+$ & $I+$ \\
\hline \multicolumn{6}{|l|}{ Monocarboxylic acids } \\
\hline Formate & I & 0 & 0 & 0 & 0 \\
\hline Acetate & 2 & $2+$ & $3+$ & $3+$ & $2+$ \\
\hline Propionate & 3 & 0 & 0 & $\mathrm{I}+$ & 0 \\
\hline Butyrate & 4 & 0 & $2+$ & $2+$ & 0 \\
\hline Pentanoate & 5 & 0 & $I+$ & $I+$ & 0 \\
\hline Hexanoate & 6 & 0 & $1+$ & $1+$ & 0 \\
\hline Octanoate & 8 & 0 & $2+$ & 0 & 0 \\
\hline Decanoate & 10 & $\mathbf{I}+$ & $3+$ & $2+$ & $I+$ \\
\hline Dodecanoate & 12 & $\mathbf{I}+$ & $3+$ & $2+$ & $2+$ \\
\hline Tetradecanoate & 14 & $2+$ & $3+$ & $2+$ & $\mathbf{I}+$ \\
\hline Octadecanoate & 18 & $2+$ & $3+$ & $2+$ & $\mathbf{I}+$ \\
\hline Eicosanoate & 20 & $2+$ & $2+$ & $2+$ & $I+$ \\
\hline \multicolumn{6}{|l|}{$n$-Alcohols } \\
\hline Methanol & $\mathbf{I}$ & 0 & 0 & 0 & 0 \\
\hline Ethanol & 2 & 0 & 0 & 0 & 0 \\
\hline Propanol & 3 & 0 & 0 & 0 & 0 \\
\hline Butanol & 4 & 0 & 0 & 0 & 0 \\
\hline Pentanol & 5 & 0 & 0 & 0 & 0 \\
\hline Undecanol & I I & $\mathbf{I}+$ & $\mathbf{I}+$ & $I+$ & $\mathbf{I}+$ \\
\hline Octadecanol & 18 & $\mathbf{I}+$ & $I+$ & $\mathbf{I}+$ & $1+$ \\
\hline \multicolumn{6}{|l|}{ Dicarboxylic acids } \\
\hline Ethanedioate & 2 & 0 & 0 & 0 & - \\
\hline Propanedioate & 3 & 0 & $2+$ & $2+$ & - \\
\hline Butanedioate & 4 & 0 & $2+$ & $2+$ & - \\
\hline Hexanedioate & 6 & 0 & 0 & $2+$ & - \\
\hline Octanedioate & 8 & 0 & 0 & $2+$ & - \\
\hline Decanedioate & 10 & 0 & $2+$ & $2+$ & - \\
\hline \multicolumn{6}{|l|}{ Acyl amides } \\
\hline Acetamide & 2 & $2+$ & $2+$ & 0 & \\
\hline Octanamide & 8 & 0 & 0 & 0 & \\
\hline Dodecanamide & 12 & 0 & 0 & 0 & \\
\hline \multicolumn{6}{|l|}{ Mixed hydrocarbons } \\
\hline White lighting kerosene & & $\mathbf{I}+$ & $3+$ & $3+$ & $3+$ \\
\hline Power kerosene & & $1+$ & $3+$ & $3+$ & $3+$ \\
\hline Industrial diesel oil & & $\mathbf{I}+$ & $3+$ & $3+$ & $3+$ \\
\hline Mobiljet A kerosene & & $\mathbf{I}+$ & $3+$ & $\mathbf{I}+$ & $3+$ \\
\hline Mobiljet B kerosene & & $2+$ & $2+$ & $3+$ & $2+$ \\
\hline Thermally stable jet fuel & & 0 & $3+$ & $3+$ & $3+$ \\
\hline Brake fiuid & & $2+$ & $1+$ & $\mathbf{I}+$ & $1+$ \\
\hline Automotive diesel oil & & $1+$ & $3+$ & $3+$ & $3+$ \\
\hline
\end{tabular}

$* 0=$ No growth; $1+=$ slight turbidity; $2+=$ moderate turbidity; $3+=$ dense turbidity; $-=$ not tested. 
lactose, maltose, mannitol, rhamnose, sucrose, xylose, arabinose, raffinose and trehalose were not fermented.

Using Bergey's Manual of Determinative Bacteriology (Breed, et al. 1957) Mycobacterium B 4 is a new species similar to $M$. smegmatis.

Table 2. Oxygen uptake $\left(Q_{\mathrm{o}_{2}}\right)$ from alkanes and fatty acids by resting cell suspensions of Torulopsis $Y 8$ grown on different substrates

\begin{tabular}{|c|c|c|c|c|c|c|}
\hline \multirow[b]{2}{*}{ Substrate } & \multirow{2}{*}{$\begin{array}{l}\text { Number } \\
\text { of carbon } \\
\text { atoms }\end{array}$} & \multicolumn{5}{|c|}{$\begin{array}{c}\text { Substrate of growth } \\
Q_{\mathrm{O}_{2}}\left(\mu \mathrm{l} . \mathrm{O}_{2} / \mathrm{mg} \text {. dry wt/hr) }\right.\end{array}$} \\
\hline & & Glucose & Acetate & $\mathrm{ADO}$ & Dodecane & Hexadecane \\
\hline \multicolumn{7}{|l|}{ n-Alkanes } \\
\hline $\begin{array}{l}\text { Heptane } \\
\text { Octane }\end{array}$ & 7 & 6 & 2 & 45 & IO & 9 \\
\hline Octane & 8 & 8 & I6 & 142 & 66 & 35 \\
\hline Nonane & 9 & 27 & 30 & 120 & 60 & 55 \\
\hline Decane & 10 & 45 & 38 & 170 & 95 & 35 \\
\hline Undecanı & I I & 9 & 13 & 95 & 37 & 115 \\
\hline Dodecane & 12 & 15 & 12 & 67 & 64 & 65 \\
\hline Tridecane & 13 & 5 & I5 & 68 & 38 & 55 \\
\hline Tetradecane & 14 & 7 & —* & - & - & 60 \\
\hline Pentadecane & 15 & 7 & I5 & 60 & 26 & 79 \\
\hline Hexadecane & 16 & 4 & 13 & 55 & 29 & 75 \\
\hline Heptadecane & 17 & 22 & 29 & 60 & 32 & 68 \\
\hline Octadecane & 18 & 0 & 13 & 40 & 26 & 39 \\
\hline Nonadecane & 19 & 2 & 20 & 45 & 20 & 30 \\
\hline Eicosane & 20 & 4 & 7 & 35 & 10 & 12 \\
\hline Docosane & 22 & 8 & 12 & 15 & 10 & I5 \\
\hline Tetracosane & 24 & 4 & 8 & I4 & II & 10 \\
\hline Octacosane & 28 & 4 & 6 & 16 & 10 & I I \\
\hline Dotriacontane & 32 & 4 & 6 & 16 & 32 & 12 \\
\hline \multicolumn{7}{|c|}{ Monocarboxylic acids } \\
\hline Formate & I & 0 & 0 & 0 & - & 0 \\
\hline Acetate & 2 & 30 & 43 & 27 & - & 50 \\
\hline Propionate & 3 & 0 & 0 & 0 & - & 0 \\
\hline Butyrate & 4 & 0 & o & 0 & - & 0 \\
\hline Hexanoate & 6 & 0 & 0 & 0 & - & 75 \\
\hline Octanoate & 8 & 0 & 0 & 22 & - & 95 \\
\hline Decanoate & 10 & 0 & 0 & 0 & - & 165 \\
\hline Undecanoate & I I & 0 & 0 & 0 & - & I I 2 \\
\hline Dodecanoate & 12 & 0 & 0 & 17 & - & 80 \\
\hline Tridecanoate & 13 & 20 & 45 & 14I & - & 90 \\
\hline Tetradecanoate & 14 & 120 & I 15 & 156 & - & 190 \\
\hline Pentadecanoate & 15 & 82 & 60 & 104 & 一 & 112 \\
\hline Hexadecanoate & I6 & 29 & 50 & 37 & - & I35 \\
\hline Heptadecanoate & 17 & 12 & - & 28 & 一 & 45 \\
\hline Octadecanoate & 18 & 18 & 5 & 2 & - & 25 \\
\hline Eicosanoate & 20 & 0 & 5 & 5 & - & 0 \\
\hline Docosanoate & 22 & 0 & 0 & 0 & - & 0 \\
\hline
\end{tabular}

Substrates able to support growth. Table I shows the results of experiments in which either Torulopsis Y 8, Pseudomonas 22, Pseudomonas I4, or Mycobacterium B 4 was inoculated into media with different sources of carbon. It is clear that organisms isolated using kerosene are best able to grow on the $n$-alkanes containing 12 to 20 carbon atoms, although Pseudomonas 22 was able to grow on the alkanes from $\mathbf{C}_{6}$ to $\mathrm{C}_{20}$. All organisms were able to use a number of mixed hydrocarbons for growth; the growth obtained was much heavier than that obtained with single $n$-alkanes. 
The ability of these organisms to grow on the $C_{1}$ to $C_{20}$ monocarboxylic acids, the $\mathrm{C}_{2}$ to $\mathrm{C}_{10}$ dicarboxylic acids, the $\mathrm{C}_{2}, \mathrm{C}_{8}$ and $\mathrm{C}_{12}$ acyl amides and several straight chain alcohols was also tested. The organisms were able to grow on a far greater range of monocarboxylic acids than $n$-alkanes and growth was much heavier with the monocarboxylic acids as substrates. The pseudomonads grew on most of the $C_{2}$ to $C_{20}$ monocarboxylic acids tested, but Torulopsis $\mathrm{Y} 8$ and Mycobacterium B 4 could not grow on the $\mathrm{C}_{3}$ to $\mathrm{C}_{8}$ monocarboxylic acids. Torulopsis $\mathrm{Y} 8$ was also unable to grow on the $C_{2}$ to $C_{10}$ dicarboxylic acids. The $C_{8}$ and $C_{12}$ acyl amides and the short chain alcohols did not support the growth of any of the organisms tested but both undecanol and octadecanol supported poor growth.

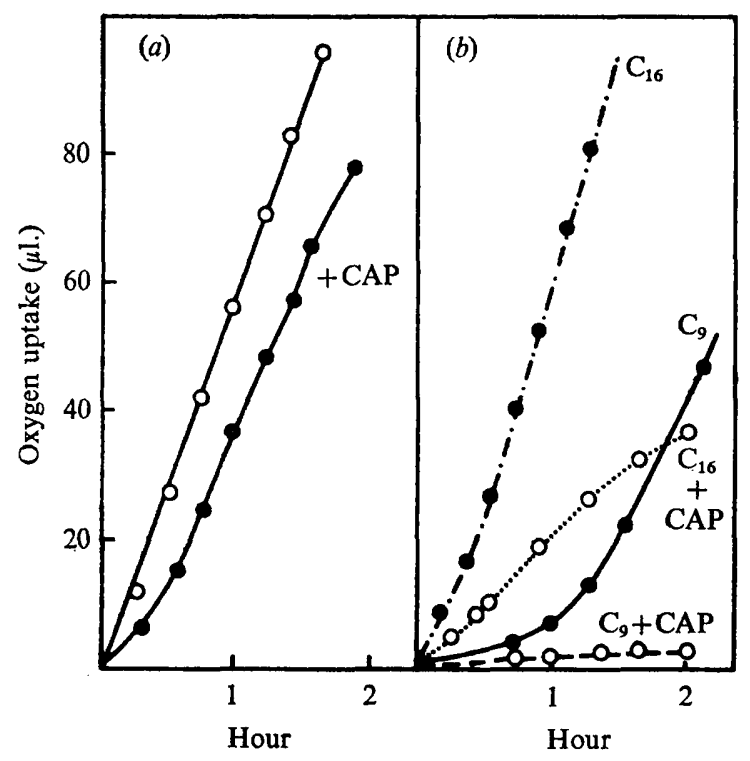

Fig. 1. Oxygen uptake ( $\mu$ l.) by cells of Mycobacterium B 4 grown on glucose. (a) Cells exposed to glucose $(\mathrm{O}-\mathrm{O})$ and glucose $+24 \mu \mathrm{g}$. chloramphenicol $/ \mathrm{ml}$. (O-O); (b) cells exposed to: hexadecane ( - - - $)$; hexadecane $+24 \mu \mathrm{g}$. chloramphenicol $/ \mathrm{ml}$. (O-..-O); nonane ( -

Substrates oxidized. The ability of washed, resting-cells of torula to take up oxygen on exposure to $n$-alkanes and to monocarboxylic acids was tested (Table 2). Torulopsis Y 8 was able to oxidize the $C_{7}$ to $C_{32} n$-alkanes regardless of the substrate on which the cells had been grown. In glucose and acetate-grown cells, the ability to oxidize alkanes was present at a low basal level and oxygen uptake increased with time until a constant rate was achieved between 0.5 and $2.5 \mathrm{hr}$. Prior growth on Automotive Diesel Oil (ADO), dodecane or hexadecane and subsequent exposure of the cells to alkanes resulted in significantly higher $Q_{\mathrm{o}_{\mathbf{a}}}$ values from zero time. Prior growth of the cells on hydrocarbons presumably induced enzyme systems in the cells.

The alkanes most readily oxidized were not analogous to the fatty acids most readily oxidized. Torulopsis $Y 8$ oxidized $C_{8}$ to $C_{13}$ alkanes fastest but fatty acids $C_{13}$ to $C_{16}$ were most readily oxidized. The $\mathrm{C}_{20}$ to $\mathrm{C}_{32}$ alkanes and acids were oxidized at a slow rate and then only after a long lag period. The $C_{1}, C_{3}, C_{4}, C_{6}, C_{8}$ and $C_{10}$ fatty acids were often toxic to the cells. Oxygen uptake on exposure to these acids gradually 
decreased with time and, in certain cases, even endogenous respiration was inhibited. The enzymes concerned in the oxidation of fatty acids by glucose-grown and acetategrown cells of Torulopsis $\mathrm{Y} 8$ were presumably induced, since these cells initially oxidized the acids at only a low basal rate but this rate increased with time. Cells grown on ADO or hexadecane exhibited a higher rate of oxygen uptake initially and this did not increase with time.

Induction of $n$-alkane oxidation. To confirm that the oxidation of $n$-alkanes was inducible, the effect of chloramphenicol (CAP) $(24 \mu \mathrm{g} . / \mathrm{ml}$.) on the oxidation of glucose, nonane and hexadecane by glucose-grown cells of Mycobacterium B 4 was tested. The results are shown in Fig. I. The lower rates of oxidation of alkanes observed in the presence of CAP suggests that the enzymes for alkane oxidation are inducible but that, in glucose-grown cells, these enzymes are present constitutively at a low concentration.

Induction of isocitric lyase by growth of organisms on hydrocarbons. Torulopsis $\mathrm{Y} 8$, Pseudomonas 22 and Mycobacterium B 4 were grown on two non-hydrocarbon substrates (glucose and acetate), two mixed hydrocarbon substrates (Mobiljet A kerosene and Mobil ADO) and two pure $n$-alkanes (dodecane and hexadecane). Cell-free extracts were assayed for isocitric lyase and the results obtained are seen in Table 3. Growth on hydrocarbons induced isocitric lyase formation; however, the amount of induction varied both from organism to organism and from substrate to substrate.

Table 3. Effect of the substrate of growth on the content of isocitric lyase in Torulopsis Y8, Pseudomonas 22 and Mycobacterium B 4

$\begin{array}{lccc}\text { Growth substrate } & \begin{array}{c}\text { Torulopsis Y } 8 \\ \text { S.A. }\end{array} & \text { Pseudomonas 22 } & \text { Mycobacterium B4 } \\ \text { Glucose } & 30 & \text { S.A. } & \text { S.A. } \\ \text { Acetate } & 550 & 10 & 40 \\ \text { Dodecane } & 120 & 60 & 600 \\ \text { Hexadecane } & \text { I40 } & 70 & 130 \\ \text { Mobiljet A } & 130 & 120 & 60 \\ \text { ADO } & -\dagger & 20 & - \\ & & 40 & - \\ & * \text { S.A. }=\text { Specific activity (units/mg. protein). } \\ & +-=\text { Not tested. }\end{array}$

\section{DISCUSSION}

The bacteria isolated for this study are representative of very different genera in the Schizomycetes but we are unable to assign them to species. Dr R. R. Colwell of Georgetown University examined Pseudomonas 22 and Dr R. E. Gordon of Rutgers University examined Mycobacterium B 4 and could not give them a species name in their respective genera. Similarly, the torula appears to be different from presently described species but we are unable to do more than place strain $Y 8$ within the genus Torulopsis. As might have been expected, all four isolates had a similar general pattern of growth on pure alkanes and fatty acids; the pseudomonads, however, could use a rather wider range of substrates for growth than the representatives of other genera. All organisms grew better on crude mixed hydrocarbons than on pure alkanes and this is probably related to the presence of more readily available impurities (especially fatty acids) in the crude hydrocarbons; this is significant for the storage life of fuels. 
Rapid oxidation of a particular alkane was not necessarily correlated with rapid oxidation of the corresponding saturated fatty acid. The results indicate that cells selected for their ability to utilize alkanes as sole source of carbon do have a basal level of enzymes capable of oxidizing hydrocarbons and cells grown on hexadecane (and other alkanes) had the same general pattern of oxidation of both alkanes and fatty acids as cells grown on non-hydrocarbon substrates. Prior growth of the organisms on alkanes did, however, induce the cells (over a wide range of chain lengths) to oxidize alkanes at a faster rate and several alkanes which were not oxidized by glucose-grown cells were oxidized by alkane-grown cells. The monocarboxylic acids were oxidized faster than the $n$-alkanes and this might be expected since the initial oxidation of the alkyl group of the alkane is already accomplished when the acid is supplied. In addition, the carboxyl group increases the polarity and solubility of the acid, thus the acid presents a far greater surface to the organism than does the corresponding alkane. The poor availability of insoluble substrates probably accounts for the long lag periods and the slow rates of oxygen uptake shown with $\mathrm{C}_{20}$ to $\mathrm{C}_{32}$ alkanes and acids.

The lack of growth on and oxidation of the short chain fatty acids is possibly due to their toxicity. The short chain acids have a detergent action on membranes and denature proteins. These effects could account for the observation that, when the $\mathrm{C}_{\mathbf{1}}$, $\mathrm{C}_{3}, \mathrm{C}_{4}, \mathrm{C}_{6}, \mathrm{C}_{8}$ and $\mathrm{C}_{10}$ fatty acids were oxidized at all, oxygen uptake was often inhibited soon after exposure to these fatty acids. In addition to toxicity, failure to metabolize certain fatty acids may be associated with lack of enzymes vital for their metabolism.

While growth of the torula on alkanes did increase its ability to oxidize fatty acids, the effect was far less pronounced with the acids than it was with the alkanes. Further, the oxidation of fatty acids by torula grown on alkanes showed no evidence that growth on the alkane had induced any particular pattern of enhanced oxidation of the fatty acids of smaller chain length than the growth-alkane (as was reported by Azoulay \& Senez, I960). This result is not totally unexpected since during $\beta$-oxidation the monocarboxylic acid intermediates are in the CoA-ester form and, in this form, they may not act as inducers of the enzymes associated with the oxidaton of the free fatty acids. The inability to demonstrate sequential induction cannot be interpreted as meaning that $\beta$-oxidation is unimportant in the oxidation of alkanes and acids in these organisms. On the contrary, the finding that the enzyme isocitric lyase was induced by growth of the organisms on alkanes is consistent with $\beta$-oxidation being important in the metabolism of these substrates. The fact that this induction was found in widely different organisms grown on very different hydrocarbon substrates indicates that the glyoxylate cycle has an important role in the metabolism of hydrocarbons by micro-organisms.

This work was supported by a grant from the University of Melbourne Research Fund.

\section{REFERENCES}

Azoulay, E. \& SENEZ, J. C. (1960). Dégredation bactérienne des hydrocarbures paraffiniques. II. Détermination des produits intermédiaires par la methode des adaptations simultanées. Annales de l'Institut Pasteur, Paris 98, 868.

Bergey's Manual of Determinative Bacteriology (1957). 7th ed. Edited by S. R. Breed, E. G. D. Murray \& N. R. Smith. Baltimore: Williams and Wilkins.

Dixon, G. H. \& Kornberg, H. L. (1959). Assay methods for key enzymes of the glyoxylate cycle. Biochemical Journal 72, 3 P. 
Foster, J. W. (I962). Hydrocarbons as substrates for micro-organisms. Antonie van Leeuwenhoek 28, 241 .

Gornall, A. G., Bardawill, C. J. \& David, M. M. (I949). Determination of serum proteins by means of the biuret reaction. Journal of Biological Chemistry 177, 75I.

Johnson, M. J. (1967). Growth of microbial cells on hydrocarbons. Science, New York 155, 1515.

Kester, A. S. \& Foster, J. W. (1963). Determinal oxidation of long-chain alkanes by bacteria. Journal of Bacteriology 85, 859 .

King, E. O., WARD, M. K. \& RANEY, D. E. (1954). Two simple media for the demonstration of pyocyanin and fluorescein. Journal of Laboratory and Clinical Medicine 44, 301.

VAN DER Linden, A. C. \& Thissse, G. J. E. (1965). The mechanisms of microbial oxidations of petroleum hydrocarbons. Advances in Enzymology 27, 469.

Lodder, J. \& Kreger-van RiJ, N. J. W. (1952). The Yeasts, a Taxonomic Study. Amsterdam: North Holland Publishing Co.

McKenna, E. J. \& Kallio, R. E. (1965). The biology of hydrocarbons. Annual Review of Microbiology 19, 183.

SKERMAN, V. B. D. (1967). A Guide to the Identification of the Genera of Bacteria. 2nd ed. Baltimore: Williams and Wilkins Company.

THIJSSE, G. J. E. \& VAN DER LINDEN, A. C. (1958). n-Alkane oxidation by a Pseudomonas. Studies on the intermediate metabolism. Antonie van Leeuwenhoek 24, 298.

Thiusse, G. J. E. \& VAN DER LiNden, A. C. (1963). Pathways of hydrocarbon dissimilation by a Pseudomonas as revealed by chloramphenicol. Antonie van Leeuwenhoek 29, 89.

TrecCani, V., Canonica, L. \& De Girolamo, M. G. (1955). Ossidazione microbica degli idrocarburi alifatici. Nota II. Ricerche culturali e manometriche sul metabolismo ossidativo delle paraffine a numero pari e dispari di atomi di $\mathrm{C}$ ad opera di microbi diversi. Annali di Microbiologia 6, 183. 